\title{
Employee Performance Assessment Decision Support Using Profile Matching Method Compared to Simple Additive Weight Addition at Dharma Buddhi University, Tangerang
}

\author{
Muhammad Subhana ${ }^{1 *}$, Yakub $^{2)}$ \\ ${ }^{1) 2)}$ STMIK Eresha \\ Jl. Raya Puspiptek No.11, Buaran, Kec. Serpong, Kota Tangerang Selatan, Banten 15310 \\ ${ }^{1)}$ muhammad.subhana@ubd.ac.id \\ ${ }^{2)}$ yakub@ubd.ac.id
}

\begin{tabular}{|c|c|}
\hline Article history: & Abstract \\
\hline $\begin{array}{l}\text { Received } 16 \text { october } 2019 ; \\
\text { Revised } 20 \text { October } 2019 ; \\
\text { Accepted } 26 \text { October } 2019 ; \\
\text { Available online } 30 \text { October } 2019\end{array}$ & $\begin{array}{l}\text { An employee performance evaluation of the Buddhist Dharma University is needed } \\
\text { to see the potential of its human resources. To get an employee performance } \\
\text { appraisal in one year requires a decision support system that is fast and measurable }\end{array}$ \\
\hline $\begin{array}{l}\text { Keywords: } \\
\text { DSS } \\
\text { profile matching, } \\
\text { Employee } \\
\text { Performance }\end{array}$ & $\begin{array}{l}\text { employee performance uses profile matching and is compared with the SAW } \\
\text { (simple additive weight) method so that the results can be properly compared. The } \\
\text { purpose of employee appraisal is so that leaders can easily obtain information about } \\
\text { employee performance ratings at Buddhii Dharma University. The results of the } \\
\text { value using the profile matching method can be recommended for salary increases } \\
\text { and positions of } 4 \text { employees. Which can be recommended for salary increases } \\
\text { there are } 17 \text { employees and those who are not eligible for salary increases and } \\
\text { positions are valued at } 12 \text { employees. And comparing with the Simple Additive } \\
\text { Weight (SAW) method, there are } 19 \text { employees who are eligible to raise salaries } \\
\text { and } 14 \text { employees who are not eligible to raise salaries and positions. }\end{array}$ \\
\hline
\end{tabular}

\section{INTRODUCTION}

Employees are very vital resources in a company or educational institution, because many employees play a role in every activity. Employee performance appraisal is an assessment process to produce high quality and dedicated employees. The leadership of the company or educational institution has a problem in being able to evaluate, in this case providing an assessment of the performance of its employees. The Dharma Buddhi University also evaluates employee performance, especially in all parts of the Dharma Buddhist University. This employee assessment is conducted at the end of each year by distributing assessment questionnaires. Then do an employee performance appraisal by counting all the number of assessment criteria. The results of the assessment are less effective and the results of the decision are slow, because the employee evaluation system has not been computerized, and an application program has not yet been made, so the leadership takes too long to make decisions in the work evaluation. To overcome the problems of the Buddhist Dharma University, it is necessary to make a decision support system for employee performance appraisal that can be accessed via the web with the profile matching method consisting of job criteria and self potential. All assessment data that has been entered will be calculated by Gap and core factor and secondary factor. Then the determination of the weights for each criterion has been made and will make it easier to make an appraisal report.

\footnotetext{
${ }^{*}$ Corresponding author
} 


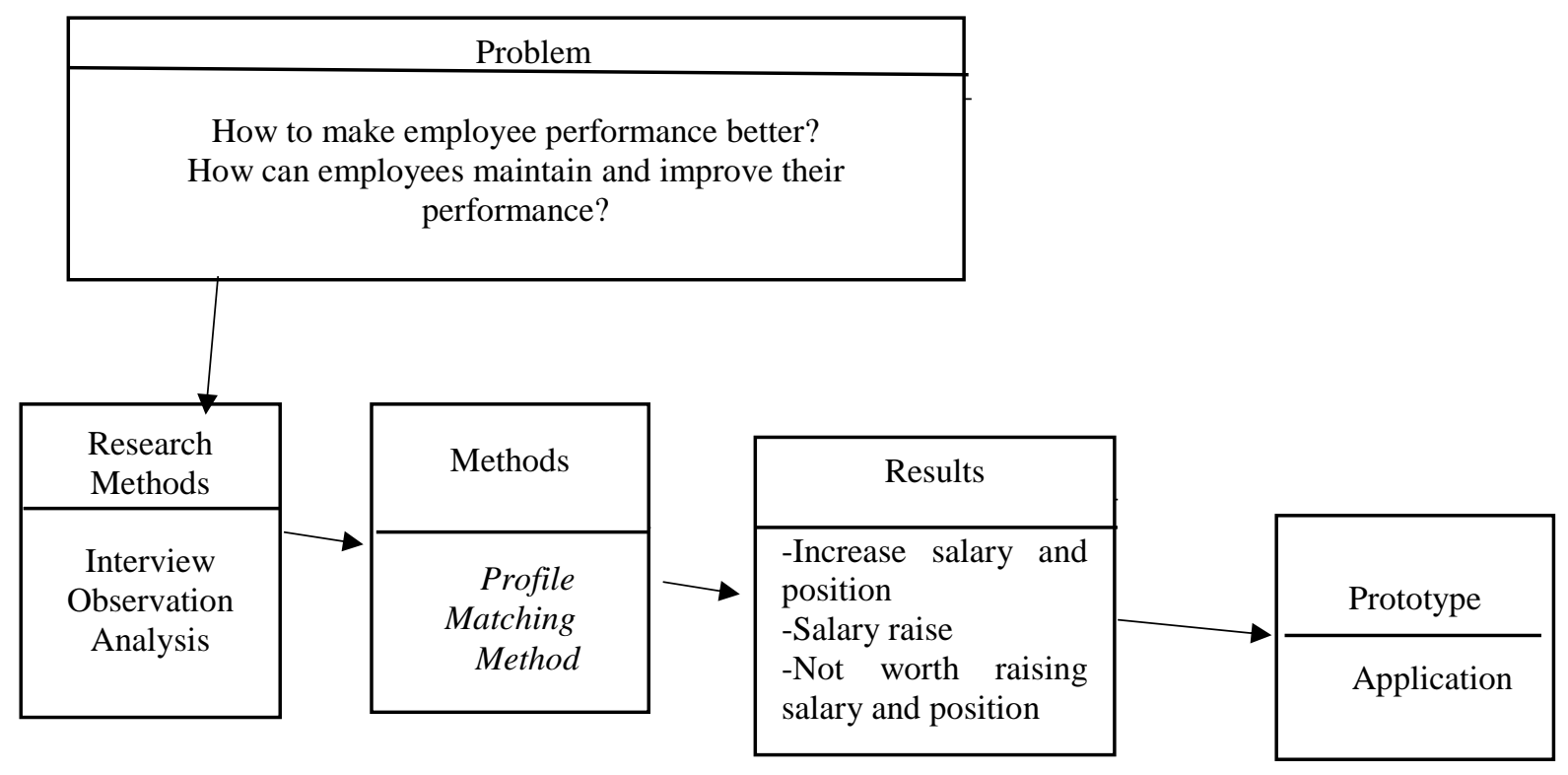

Fig 1. Framework

Employee performance appraisal can be seen from the side of the problems that exist in tangerang Buddhi Dharma University, by interviewing, observing and analyzing existing problems, we make a decision support system for employee performance appraisal so that results can be seen quickly through the profile matching method accessed through This web and Profile Matching method are compared with the SAW (Simple Additive Weight) method so that the results can be compared properly.

\section{RELATED WORKS/LITERATURE REVIEW}

\begin{tabular}{|c|c|c|c|c|c|c|c|}
\hline No & Tittle & Abstract & Object & Method & Results & Conclusion & Keyword \\
\hline 1 & $\begin{array}{l}\text { Decision } \\
\text { support system } \\
\text { for teacher } \\
\text { performance } \\
\text { assessment } \\
\text { using the } \\
\text { profile } \\
\text { matching } \\
\text { method [1] } \\
\text { Ari Suhartanto, } \\
\text { Kusrini, } \\
\text { Henderi }\end{array}$ & $\begin{array}{l}\text { By applying the Profile } \\
\text { Matching method to } \\
\text { assess Pedagogical } \\
\text { Competence as a } \\
\text { process of evaluating } \\
\text { the performance of } \\
\text { outstanding teachers } \\
\text { for the scope of the } \\
\text { Office of Education } \\
\text { and Culture District. } \\
\text { Madiun can increase } \\
\text { the objectivity and } \\
\text { accuracy of data. The } \\
\text { data collected is a } \\
\text { history of teacher } \\
\text { performance appraisal } \\
\text { in the form of } \\
\text { documents and } \\
\text { statements as well as } \\
\text { supporting data in the } \\
\text { form of documents of } \\
\text { the rules and } \\
\text { procedures for the } \\
\text { performance } \\
\text { evaluation process for }\end{array}$ & $\begin{array}{l}\text { Emplo } \\
\text { yee } \\
\text { perfor } \\
\text { mance } \\
\text { apprais } \\
\text { al }\end{array}$ & $\begin{array}{l}\text { Case study } \\
\text { research (case } \\
\text { study) is } \\
\text { different from } \\
\text { survey research. } \\
\text { In the survey } \\
\text { research the } \\
\text { sample size is } \\
\text { quite extensive } \\
\text { while in the case } \\
\text { study the } \\
\text { number of } \\
\text { samples taken is } \\
\text { very small or } \\
\text { only a few } \\
\text { people. But the } \\
\text { similarity survey } \\
\text { between survat } \\
\text { research and } \\
\text { case studies is } \\
\text { that both explore } \\
\text { the phenomeno. } \\
\text { In this study, the } \\
\text { authors } \\
\text { collected data }\end{array}$ & $\begin{array}{l}\text { The final result is } \\
\text { that alternative Nur } \\
\text { Rahayuningtyas } \\
\text { gets the highest } \\
\text { result with a value } \\
\text { of } 3,820 \text { adrift of } \\
0.021 \text { with Sulasmi } \\
\text { alternative and } \\
\text { quite far adrift of } \\
\text { Sri Harnanik's } \\
\text { alternative by } \\
0.155 \text {. }\end{array}$ & $\begin{array}{l}\text { Teacher } \\
\text { performance } \\
\text { appraisal system } \\
\text { for Pedagogical } \\
\text { Competence } \\
\text { using the Profile } \\
\text { Matching method } \\
\text { that has been } \\
\text { applied has an } \\
\text { accuracy rate of } \\
\text { 95.67\%. This is } \\
\text { due to the } \\
\text { decision making } \\
\text { mechanism by } \\
\text { assuming that the } \\
\text { ideal level of } \\
\text { predictor } \\
\text { variables must be } \\
\text { fulfilled by } \\
\text { subjects. } \\
\text { Assessment using } \\
\text { SPK profile } \\
\text { matching has a } \\
\text { better level of } \\
\text { objectivity }\end{array}$ & $\begin{array}{l}\text { Decision } \\
\text { Support } \\
\text { System, } \\
\text { Teacher } \\
\text { Performanc } \\
\text { e } \\
\text { Assessment } \\
\text {, Profile } \\
\text { Matching }\end{array}$ \\
\hline
\end{tabular}




\begin{tabular}{|c|c|c|c|c|c|c|c|}
\hline & & $\begin{array}{l}\text { outstanding teachers. } \\
\text { Based on the testing of } \\
\text { the system, the level of } \\
\text { accuracy of the } \\
\text { assessment obtained } \\
\text { with three alternative } \\
\text { samples has an average } \\
\text { yield of } 95.67 \% \text {, which } \\
\text { is calculated from } \\
\text { comparing with the } \\
\text { average final score of } \\
\text { pedagogical } \\
\text { competency } \\
\text { assessment manually. } \\
\text { The difference in } \\
\text { average number is } \\
4.33 \% \text { smaller because } \\
\text { the decision making } \\
\text { mechanism with the } \\
\text { profile matching } \\
\text { method assumes that } \\
\text { there is an ideal level } \\
\text { of predictor variables } \\
\text { that must be met by } \\
\text { subjects. Assessment } \\
\text { using Profile Matching } \\
\text { has a better level of } \\
\text { objectivity because to } \\
\text { measure the value of } \\
\text { each indicator the } \\
\text { assessment variable is } \\
\text { lowered again by sub- } \\
\text { indicators and } \\
\text { weighted using } \\
\text { assessment parameters } \\
\text { and calculated using } \\
\text { decision m making } \\
\text { mechanisms by by } \\
\text { assuming that there is } \\
\text { an ideal level of } \\
\text { predictor variables that } \\
\text { must be met by subject. } \\
\text { In contrast to the } \\
\text { manual assessment } \\
\text { process which only } \\
\text { includes the value of } \\
\text { the level of fullness of } \\
\text { each indicator by } \\
\text { writing down numbers } \\
\text { and counting only by } \\
\text { adding them up. }\end{array}$ & & $\begin{array}{l}\text { and described } \\
\text { the teacher } \\
\text { performance } \\
\text { appraisal } \\
\text { process on } \\
\text { Pedagogic } \\
\text { competencies } \\
\text { carried out by } \\
\text { teacher } \\
\text { performance } \\
\text { appraisers } \\
\text { officials in } \\
\text { accordance with } \\
\text { the actual } \\
\text { conditions } \\
\text { occurring at the } \\
\text { study site and } \\
\text { weighted the } \\
\text { assessment } \\
\text { parameters of } \\
\text { indicators on } \\
\text { Pedagogic } \\
\text { competencies to } \\
\text { determine } \\
\text { scores } \\
\text { produce to } \\
\text { pedagogical } \\
\text { competency } \\
\text { scores. }\end{array}$ & & $\begin{array}{l}\text { because to } \\
\text { measure the value } \\
\text { of each indicator } \\
\text { the assessment } \\
\text { variable is } \\
\text { lowered again } \\
\text { with sub- } \\
\text { indicators and } \\
\text { weighted using } \\
\text { assessment } \\
\text { parameters and is } \\
\text { calculated using a } \\
\text { decision-making } \\
\text { mechanism by } \\
\text { assuming that } \\
\text { there is an ideal } \\
\text { level of predictor } \\
\text { variables that } \\
\text { must be met by } \\
\text { subjects. }\end{array}$ & \\
\hline 2 & $\begin{array}{l}\text { Web-based } \\
\text { lecturer } \\
\text { assessment } \\
\text { information } \\
\text { system uses the } \\
\text { profile } \\
\text { matching } \\
\text { method. [2] } \\
\text { Moedjiono, } \\
\text { Ardie Halim } \\
\text { Wijaya, Aries } \\
\text { Kusdaryono }\end{array}$ & $\begin{array}{l}\text { The evaluation of } \\
\text { lecturers' performance } \\
\text { appraisal activities in } \\
\text { tertiary institutions is } \\
\text { carried out every } \\
\text { semester with } \\
\text { give questionnaire } \\
\text { papers to students s } \\
\text { aat before the end of } \\
\text { the semester } \\
\text { examination of the } \\
\text { subject concerned } \\
\text { begins. This makes the } \\
\text { answers to the } \\
\text { questionnaire } \\
\text { inaccurate, because it } \\
\text { takes time to fill out }\end{array}$ & $\begin{array}{l}\text { Lecture } \\
\mathrm{r} \\
\text { perfor } \\
\text { mance } \\
\text { evaluat } \\
\text { ion }\end{array}$ & & $\begin{array}{l}\text { Test results are } \\
\text { obtained } \\
\text { lecturer } \\
\text { performance } \\
\text { appraisal process } \\
\text { becomes } \\
\text { faster and more } \\
\text { accurate than ever } \\
\text { with si si stem, } \\
\text { manual the } \\
\text { besides that the } \\
\text { system } \\
\text { This new can be } \\
\text { accepted by para } \\
\text { the user. }\end{array}$ & $\begin{array}{l}\text { 1. Prototype } \\
\text { system } \\
\text { supporters } \\
\text { This web based } \\
\text { decision has been } \\
\text { tested } \\
\text { with the black } \\
\text { box testing } \\
\text { method and } \\
\text { the quality is } \\
\text { tested based on } \\
\text { ISO Test results } \\
\text { 9126. Test } \\
\text { obtained } \\
\text { lecturer } \\
\text { performance } \\
\text { appraisal process } \\
\text { becomes }\end{array}$ & $\begin{array}{l}\text { Web-based } \\
\text { prototype, } \\
\text { decision } \\
\text { support } \\
\text { system, } \\
\text { profile } \\
\text { matching, } \\
\text { assessment } \\
\text { questionnai } \\
\text { re, lecturer } \\
\text { performanc } \\
\text { e evaluation } \\
\text { prototype }\end{array}$ \\
\hline
\end{tabular}




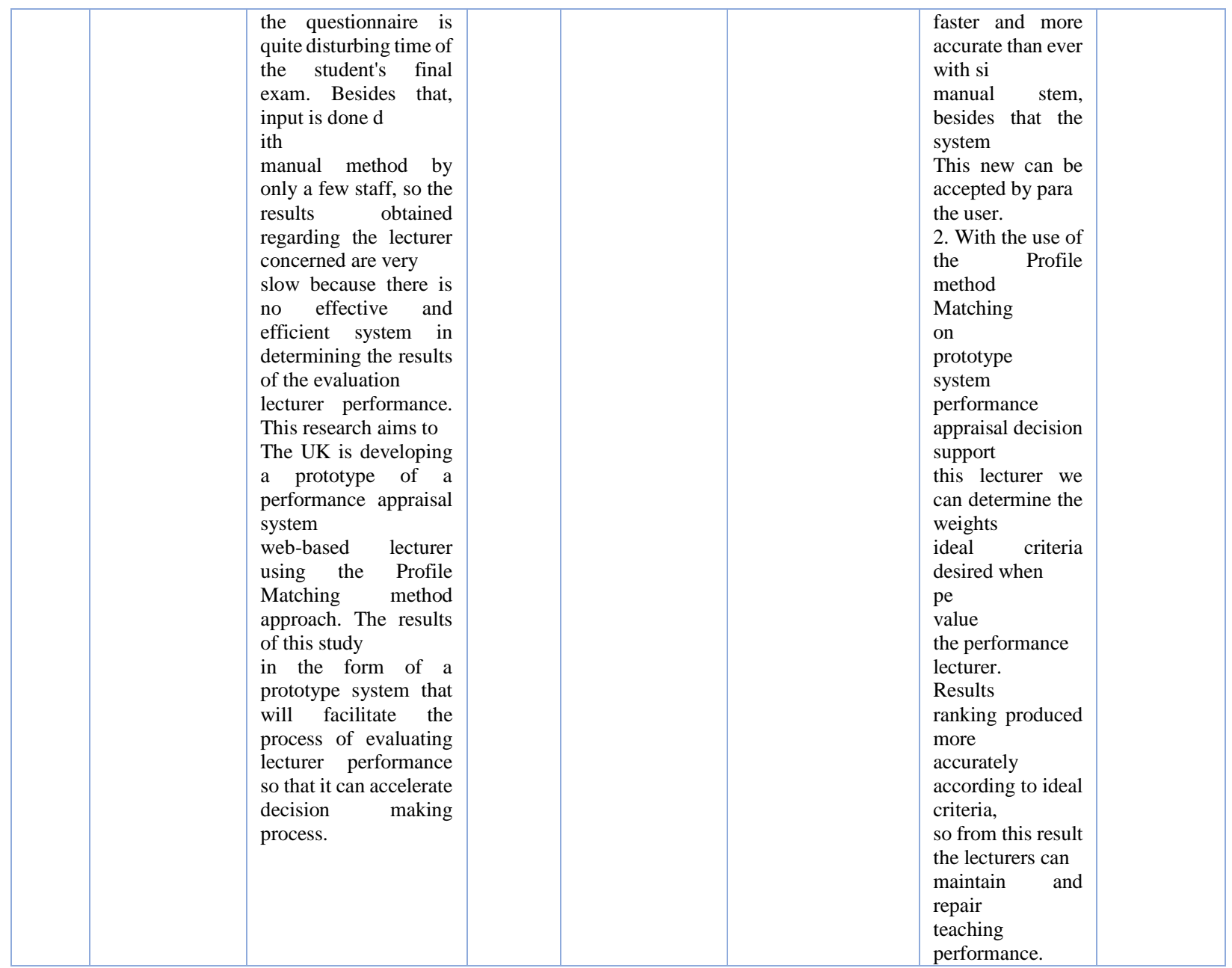

\section{METHODS}

Profile Matching is a research method that can be used in decision support systems, the competency assessment process is carried out by comparing one value profile with several other competency value profiles, so that the results of the difference between the needs of the competencies needed are known, the difference between these competencies is called a gap, where the smaller the gap the higher the value.

According to Kusrini (2007) [3] the profile matching method is a method that is often used as a mechanism in decision making by assuming that there is an ideal level of predictor variables that must be met by the subjects studied, rather than the minimum level that must be met or passed. In the profile matching process, it is broadly a process of comparing the actual data value of a profile to be assessed with the expected profile value, so that the competency differences (also called gaps) can be known, the smaller the gap produced, the greater the value weights. The data analysis techniques are as follows:

\section{Weighting}

The first step is weighting. At this stage the difference is made based on the results of the questionnaire with the target achievement value of each of the existing criteria. In ranking the criteria for their assessment in each gap, weights are given according to the following table: 


\begin{tabular}{|l|r|r|l|}
\hline No. & $\begin{array}{l}\text { Gap Difference } \\
\text { in }\end{array}$ & $\begin{array}{l}\text { Weight } \\
\text { Value }\end{array}$ & \multicolumn{1}{l|}{ Remarks } \\
\hline 1 & 0 & 5 & Competence as needed \\
\hline 2 & 1 & 4,5 & Individual competence is 1 level / level \\
\hline 3 & -1 & 4 & Individual competence is less than 1 level / level \\
\hline 4 & 2 & 3,5 & Individual competence has an excess of 2 levels / levels \\
\hline 5 & -2 & 3 & Individual competencies lacking 2 levels / levels \\
\hline 6 & 3 & 2,5 & Individual competencies are over 3 levels / level \\
\hline 7 & -3 & 2 & Individual competencies lacking 3 levels / levels \\
\hline 8 & 4 & 1,5 & Individual competence is over 4 levels / level \\
\hline 9 & -4 & 1 & Individual competencies lacking 4 levels / levels \\
\hline
\end{tabular}

2. Core and Secondary Factor Grouping

After determining the weight of the required gap value criteria, then each criterion is grouped again into two groups namely core factor and secondary factor. This grouping aims to get the main factors and supporting factors of the criteria that exist in employee performance appraisal. The formula for calculating the core factor and secondary factor is as follows:

a. Core Factor (Main Factor)

Core factors are the most important criteria in evaluating employee performance, which is expected to produce optimal performance. To calculate the core factor the formula is used:

$$
N C F \frac{N C}{I C}
$$

Information:
$\mathrm{NCF}$
$\mathrm{NC}$
: Average value of core factor
IC
: Total number of core factor values
: Number of core factor items

b. Secondary factor (supporting factor)

Secondary factor is the criteria that exist in the core factor. To calculate the secondary factor a formula is used

$$
N S . F \frac{N S}{I S}
$$

Information:

NSF : The average value of the secondary factor

NS : The total number of secondary factors

IS $\quad$ : Number of secondary factor items

3. Calculation of Total Value

From the calculation of core factors and secondary factors of each criterion, then the total value of each criterion is estimated, which is estimated to affect the performance of each profile. To calculate the total value of each criterion, a formula is used

$$
N=(X) \% N C F+/ X \% N S F
$$

Information:

$\mathrm{N}$

: the total value of each aspect

NCF

: Core factor average value

NSF

: The average value of the secondary factor

(X)\%

: The percentage value entered

4. Ranking 
The final result of the profile matching process is the total employee performance appraisal that is eligible for salary and position increases or salary increases only and is not eligible for recommendations for salary and position increases. Determination refers to ranking on the calculation results shown by the formula:

Ranking $=50 \% N C F+/ 50 \% N S F$

Information:

$\mathrm{NCF}$

NSF

\author{
: Core factor value \\ : Secondary factor values
}

The Simple Additive Weighting (SAW) method is the most well-known method and is widely used in meetings related to Multiple Attribute Decision Making (MADM) which is used to find optimal alternatives from adding alternatives with certain criteria.

Additive Weighting Method (SAW), often also known as the weighted sum method. The basic concept of this method is to find a weighted sum of performance appraisals on each alternative on all attributes [4].

The SAW method requires the decision matrix normalization process $(\mathrm{X})$ to a scale that can be compared with all available alternative ratings:

Where:

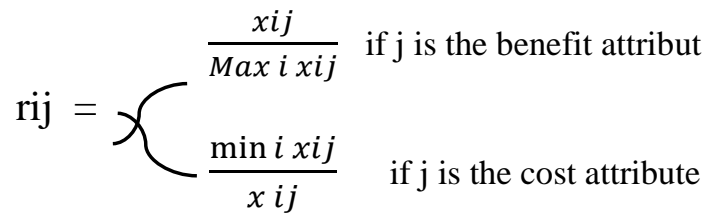
rij $=$ normalized performance rating.
Max i = maximum value of each row and column.
$\min \mathrm{i}=$ minimum value of each row and column.
$\mathrm{Xij} \quad=$ row and column of the matrix

(rij) is a normalized performance rating of alternatives on the attributes $\mathrm{i}=1,2, \ldots, \mathrm{m}$ and $\mathrm{j}=1,2, \ldots, \mathrm{n}$.

Determination of the preference value for each Vi alternative is given as:

$\mathrm{vi} \quad=$ Final value of the alternative

$$
v i \sum_{j=1}^{n} w j r i j
$$

wj $\quad=$ Weight that has been determined

rij $\quad=$ Normalization matrix

A greater Vi value indicates that the Ai alternative is preferred

Decision support system is a computer-based interactive application that combines data and mathematical models to help the decision making process in handling a problem [5].

There are three main aspects in SPK, namely:

1. Data, the data used in DSS is data taken from a data warehouse in an organization that has been categorized based on needs.

2. The mathematical model, is part of analyzing data and functions to convert data into information and knowledge that is useful for decision making.

3. User interface. This aspect is an aspect that is directly seen and interacts with the end user or in this case the decision holder. The data displayed must provide valid, reliable information that can support decision making 
Table 3. Weight Criteria for work and self potential

\begin{tabular}{|c|c|}
\hline Criteria & Bobot (\%) \\
\hline Occupation & 50 \\
\hline Self-potential & 50 \\
\hline
\end{tabular}

Table 4. Weight Assessment Method Profile Matching

\begin{tabular}{|c|l|l|l|}
\hline No & $\begin{array}{c}\text { Grading } \\
\text { percent }\end{array}$ & $\begin{array}{c}\text { Assessment of Profile } \\
\text { Matching methods }\end{array}$ & \multicolumn{1}{c|}{ Information } \\
\hline 1 & $89,6 \%$ & 4.60 & Worth raise salary and position \\
\hline 2 & $87,2 \%$ & 4.5 & Raise salary \\
\hline 3 & $83,6 \%$ & 4.4 & Not worth raising salary and position \\
\hline
\end{tabular}

Table 5. Weight Assessment Method Simple Additive Weighting (SAW)

\begin{tabular}{|l|l|l|}
\hline No & SAW Value range & Information \\
\hline 1 & $<0.93$ & Not worth raising salary and position \\
\hline 2 & $0.94-0.97$ & Raise salary \\
\hline 3 & $>0.98$ & Worth raise salary and position \\
\hline
\end{tabular}

Table 6. Ordinal Scale (Assessment of Job Criteria and Self Potential)

\begin{tabular}{|l|l|}
\hline Target Value & \multicolumn{1}{|c|}{ Information } \\
\hline 1 & very little \\
\hline 2 & Less \\
\hline 3 & Enough \\
\hline 4 & Well \\
\hline 5 & Very well \\
\hline
\end{tabular}

\section{ReSults}

1. Calculation of employee work (A)

2. Standard Value (B)

3. A - B $=$ Weight gap results

4. Core factors and secondary factors

Table 7. Employee Job Gap Assessment

\begin{tabular}{|l|l|l|l|l|l|l|l|l|c|c|c|c|c|c|c|c|c|c|c|}
\hline \multicolumn{10}{|c|}{ Employee Job Appraisal (A) } & \multicolumn{1}{|c|}{ Campus standard grade (B) } & \multicolumn{3}{|c|}{ Number of gaps (A - B) } \\
\hline No & Occupation & $\mathbf{1}$ & $\mathbf{2}$ & $\mathbf{3}$ & $\mathbf{4}$ & $\mathbf{5}$ & $\mathbf{6}$ & \multicolumn{3}{|c|}{ Standard campus values } & 1 & 2 & 3 & 4 & 5 & 6 \\
\hline 1 & Rudy & 5 & 5 & 4 & 5 & 4 & 4 & 5 & 5 & 5 & 4 & 4 & 5 & 0 & 0 & -1 & 1 & 0 & -1 \\
\hline 2 & Fenarly & 5 & 4 & 4 & 4 & 5 & 4 & 5 & 5 & 5 & 4 & 4 & 5 & 0 & -1 & -1 & 0 & 1 & -1 \\
\hline 3 & Fidellis & 5 & 4 & 4 & 4 & 4 & 4 & 5 & 5 & 5 & 4 & 4 & 5 & 0 & -1 & -1 & 0 & 0 & -1 \\
\hline 4 & Wita & 4 & 4 & 4 & 4 & 4 & 4 & 5 & 5 & 5 & 4 & 4 & 5 & -1 & -1 & -1 & 0 & 0 & -1 \\
\hline 5 & Rina & 5 & 4 & 5 & 4 & 4 & 4 & 5 & 5 & 5 & 4 & 4 & 5 & 0 & -1 & 0 & 0 & 0 & -1 \\
\hline 6 & Yuni & 4 & 4 & 4 & 5 & 5 & 4 & 5 & 5 & 5 & 4 & 4 & 5 & -1 & -1 & -1 & 1 & 1 & -1 \\
\hline 7 & Jose fung & 4 & 4 & 5 & 4 & 4 & 5 & 5 & 5 & 5 & 4 & 4 & 5 & -1 & -1 & 0 & 0 & 0 & 0 \\
\hline 8 & Hartana & 4 & 5 & 4 & 5 & 4 & 5 & 5 & 5 & 5 & 4 & 4 & 5 & -1 & 0 & -1 & 1 & 0 & 0 \\
\hline 9 & Hary & 4 & 5 & 4 & 4 & 4 & 4 & 5 & 5 & 5 & 4 & 4 & 5 & -1 & 0 & -1 & 0 & 0 & -1 \\
\hline 10 & Andi & 5 & 5 & 4 & 5 & 4 & 5 & 5 & 5 & 5 & 4 & 4 & 5 & 0 & 0 & -1 & 1 & 0 & 0 \\
\hline 11 & Akbar & 5 & 5 & 4 & 5 & 4 & 4 & 5 & 5 & 5 & 4 & 4 & 5 & 0 & 0 & -1 & 1 & 0 & -1 \\
\hline 12 & Subhana & 5 & 4 & 4 & 4 & 5 & 4 & 5 & 5 & 5 & 4 & 4 & 5 & 0 & -1 & 1 & 0 & 1 & -1 \\
\hline 13 & Iskandar & 5 & 4 & 4 & 4 & 4 & 4 & 5 & 5 & 5 & 4 & 4 & 5 & 0 & -1 & -1 & 0 & 0 & -1 \\
\hline 14 & Frendy & 4 & 4 & 4 & 4 & 4 & 4 & 5 & 5 & 5 & 4 & 4 & 5 & -1 & -1 & -1 & 0 & 0 & -1 \\
\hline 15 & Chatrine & 5 & 4 & 5 & 4 & 4 & 4 & 5 & 5 & 5 & 4 & 4 & 5 & 0 & -1 & 0 & 0 & 0 & -1 \\
\hline
\end{tabular}




\begin{tabular}{|c|c|c|c|c|c|c|c|c|c|c|c|c|c|c|c|c|c|c|c|}
\hline 16 & Abidin & 4 & 4 & 4 & 5 & 5 & 4 & 5 & 5 & 5 & 4 & 4 & 5 & -1 & -1 & -1 & 1 & 1 & -1 \\
\hline 17 & Sutandi & 4 & 4 & 5 & 4 & 4 & 5 & 5 & 5 & 5 & 4 & 4 & 5 & -1 & -1 & 0 & 0 & 0 & 0 \\
\hline 18 & Benny & 4 & 5 & 4 & 5 & 4 & 5 & 5 & 5 & 5 & 4 & 4 & 5 & -1 & 0 & -1 & 1 & 0 & 0 \\
\hline 19 & Susanto & 4 & 5 & 4 & 4 & 4 & 4 & 5 & 5 & 5 & 4 & 4 & 5 & -1 & 0 & -1 & 0 & 0 & -1 \\
\hline 20 & Septian & 5 & 5 & 4 & 5 & 4 & 5 & 5 & 5 & 5 & 4 & 4 & 5 & 0 & 0 & -1 & 1 & 0 & 0 \\
\hline 21 & Anik & 5 & 5 & 4 & 5 & 4 & 4 & 5 & 5 & 5 & 4 & 4 & 5 & 0 & 0 & -1 & 1 & 0 & -1 \\
\hline 22 & Saipul & 5 & 4 & 4 & 4 & 5 & 4 & 5 & 5 & 5 & 4 & 4 & 5 & 0 & -1 & -1 & 0 & 1 & -1 \\
\hline 23 & Anwar & 5 & 4 & 4 & 4 & 4 & 4 & 5 & 5 & 5 & 4 & 4 & 5 & 0 & -1 & -1 & 0 & 0 & 1 \\
\hline 24 & Gocang & 4 & 4 & 4 & 4 & 4 & 4 & 5 & 5 & 5 & 4 & 4 & 5 & -1 & -1 & -1 & 0 & 0 & -1 \\
\hline 25 & Dhea & 5 & 4 & 5 & 4 & 4 & 4 & 5 & 5 & 5 & 4 & 4 & 5 & 0 & -1 & 0 & 0 & 0 & -1 \\
\hline 26 & Richat & 4 & 4 & 4 & 5 & 5 & 4 & 5 & 5 & 5 & 4 & 4 & 5 & -1 & -1 & -1 & 1 & 1 & -1 \\
\hline 27 & Abdul & 4 & 4 & 5 & 4 & 4 & 5 & 5 & 5 & 5 & 4 & 4 & 5 & -1 & -1 & 0 & 0 & 0 & 0 \\
\hline 28 & Yakub & & 5 & 4 & 5 & 4 & 5 & 5 & 5 & 5 & 4 & 4 & 5 & -1 & 0 & -1 & 1 & 0 & 0 \\
\hline 29 & Roni & 4 & 5 & 4 & 4 & 4 & 4 & 5 & 5 & 5 & 4 & 4 & 5 & -1 & 0 & -1 & 0 & 0 & -1 \\
\hline 30 & Arol & 5 & 5 & 4 & 5 & 4 & 5 & 5 & 5 & 5 & 4 & 4 & 5 & 0 & 0 & -1 & 1 & 0 & 0 \\
\hline 31 & Alysia & 5 & 5 & 4 & 5 & 4 & 4 & 5 & 5 & 5 & 4 & 4 & 5 & 0 & 0 & -1 & 1 & 0 & 0 \\
\hline 32 & Budi & 5 & 4 & 4 & 4 & 5 & 4 & 5 & 5 & 5 & 4 & 4 & 5 & 0 & -1 & -1 & 0 & 1 & -1 \\
\hline 33 & Tomi & 5 & 4 & 4 & 4 & 4 & 4 & 5 & 5 & 5 & 4 & 4 & 5 & 0 & -1 & -1 & 0 & 0 & -1 \\
\hline
\end{tabular}

Calculation of employee job appraisal $(\mathrm{A})+$ Campus default value $(\mathrm{B})=$ Number of gaps. The results are combined in the table as follows:

Table 8. Job Gap Equation Table

\begin{tabular}{|c|c|c|c|c|c|c|c|c|c|c|c|}
\hline & & \multicolumn{6}{|c|}{$\begin{array}{l}\text { Equation of the results of the gap } \\
\text { (A - B) }\end{array}$} & & \multirow[b]{3}{*}{$\begin{array}{l}\text { Secondary } \\
\text { Factors }\end{array}$} & \multirow[b]{3}{*}{$\begin{array}{l}\text { Calculation } \\
\text { of CF \& SF }\end{array}$} & \multirow[b]{3}{*}{$\begin{array}{l}\text { Total } \\
\text { Value }\end{array}$} \\
\hline & & $\mathbf{A}$ & B & C & D & $\mathbf{E}$ & F & & & & \\
\hline No & Occupation & 1 & 2 & 3 & 4 & 5 & 6 & $\begin{array}{l}\text { Core } \\
\text { Factors }\end{array}$ & & & \\
\hline 1 & Rudy & 5 & 5 & 4 & 4.5 & 5 & 4 & 4.5 & 4.75 & $\begin{array}{l}(60 \% * 4.5)+ \\
(40 \% * 4.75)\end{array}$ & 4.6 \\
\hline 2 & Fenarly & 5 & 4 & 4 & 5 & 4.5 & 4 & 4.37 & 4.5 & $\begin{array}{l}(60 \% * 4.37)+ \\
(40 \% * 4.5)\end{array}$ & 4.42 \\
\hline 3 & Fidellis & 5 & 4 & 4 & 5 & 5 & 4 & 4.5 & 4.5 & $\begin{array}{l}(60 \% * 4.5)+ \\
(40 \% * 4.5)\end{array}$ & 4.5 \\
\hline 4 & Wita & 4 & 4 & 4 & 5 & 5 & 4 & 4.25 & 4.5 & $\begin{array}{l}(60 \% * 4.25)+ \\
(40 \% * 4.5)\end{array}$ & 4.35 \\
\hline 5 & Rina & 5 & 4 & 5 & 5 & 5 & 4 & 4.75 & 4.5 & $\begin{array}{l}(60 \% * 4.75)+ \\
(40 \% * 4.5)\end{array}$ & 4.65 \\
\hline 6 & Yuni & 4 & 4 & 4 & 4.5 & 4.5 & 4 & 4.12 & 4.25 & $\begin{array}{l}(60 \% * 4.12)+ \\
(40 \% * 4.25)\end{array}$ & 4.17 \\
\hline 7 & Jose fung & 4 & 4 & 5 & 5 & 5 & 5 & 4.75 & 4.5 & $\begin{array}{l}(60 \% * 4.75)+ \\
(40 \% * 4,5)\end{array}$ & 4.65 \\
\hline
\end{tabular}




\begin{tabular}{|c|c|c|c|c|c|c|c|c|c|c|c|}
\hline 8 & Hartana & 4 & 5 & 4 & 4.5 & 5 & 5 & 4.5 & 4.75 & $\begin{array}{l}(60 \% * 4.5)+ \\
(40 \% * 4,75)\end{array}$ & 4.65 \\
\hline 9 & Hary & 4 & 5 & 4 & 5 & 5 & 4 & 4.25 & 5 & $\begin{array}{l}(60 \% * 4.25)+ \\
(40 \% * 5)\end{array}$ & 4.55 \\
\hline 10 & Andi & 5 & 5 & 4 & 4.5 & 5 & 5 & 4.75 & 4.75 & $\begin{array}{l}(60 \% * 4.75)+ \\
(40 \% * 4,75)\end{array}$ & 4.75 \\
\hline 11 & Akbar & 5 & 5 & 4 & 4.5 & 5 & 5 & 4.75 & 4.75 & $\begin{array}{l}(60 \% * 4.75)+ \\
(40 \% * 4,75)\end{array}$ & 4.75 \\
\hline 12 & Subhana & 5 & 4 & 4 & 5 & 4.5 & 4 & 4.37 & 4.75 & $\begin{array}{l}60 \% * 4.37)+ \\
(40 \% * 4,75)\end{array}$ & 4.52 \\
\hline 13 & Iskandar & 5 & 4 & 4 & 5 & 5 & 4 & 4.5 & 4.5 & $\begin{array}{l}(60 \% * 4.5)+ \\
(40 \% * 4,5)\end{array}$ & 4.5 \\
\hline 14 & Frendy & 4 & 4 & 4 & 5 & 5 & 4 & 4.25 & 4.5 & $\begin{array}{l}(60 \% * 425)+ \\
(40 \% * 4,5)\end{array}$ & 4.35 \\
\hline 15 & Chatrine & 5 & 4 & 5 & 5 & 5 & 4 & 4.75 & 4.5 & $\begin{array}{l}(60 \% * 4.75)+ \\
(40 \% * 4,5)\end{array}$ & 4.65 \\
\hline 16 & Abidin & 4 & 4 & 4 & 4.5 & 4.5 & 4 & 4.12 & 4.25 & $\begin{array}{l}(60 \% * 4.12)+ \\
(40 \% * 4,25)\end{array}$ & 4.35 \\
\hline 17 & Sutandi & 4 & 4 & 5 & 5 & 5 & 5 & 4.75 & 4.5 & $\begin{array}{l}(60 \% * 4.75)+ \\
(40 \% * 4.5)\end{array}$ & 4.65 \\
\hline 18 & Benny & 4 & 5 & 4 & 4.5 & 5 & 5 & 4.5 & 4.75 & $\begin{array}{l}(60 \% * 4.5)+ \\
(40 \% * 4.75)\end{array}$ & 4.65 \\
\hline 19 & Susanto & 4 & 5 & 4 & 5 & 5 & 4 & 4.25 & 5 & $\begin{array}{l}(60 \% * 4.25)+ \\
(40 \% * 5)\end{array}$ & 4.55 \\
\hline 20 & Septian & 5 & 5 & 4 & 4.5 & 5 & 5 & 4.75 & 4.75 & $\begin{array}{l}(60 \% * 4.75)+ \\
(40 \% * 4.75)\end{array}$ & 4.75 \\
\hline 21 & Anik & 5 & 5 & 4 & 4.5 & 5 & 4 & 4.5 & 4.75 & $\begin{array}{l}(60 \% * 4.5)+ \\
(40 \% * 4.75)\end{array}$ & 4.6 \\
\hline 22 & Saipul & 5 & 4 & 4 & 5 & 4.5 & 4 & 4.37 & 4.5 & $\begin{array}{l}(60 \% * 4.37)+ \\
(40 \% * 4.5)\end{array}$ & 4.38 \\
\hline 23 & Anwar & 5 & 4 & 4 & 5 & 5 & 4 & 4.5 & 4.5 & $\begin{array}{l}(60 \% * 4.5)+ \\
(40 \% * 4.5)\end{array}$ & 4.5 \\
\hline 24 & Gocang & 4 & 4 & 4 & 5 & 5 & 4 & 4.25 & 4.5 & $\begin{array}{l}(60 \% * 4.25)+ \\
(40 \% * 4.5)\end{array}$ & 4.35 \\
\hline 25 & Dhea & 5 & 4 & 5 & 5 & 5 & 4 & 4.75 & 4.5 & $\begin{array}{l}(60 \% * 4.75)+ \\
(40 \% * 4.5)\end{array}$ & 4.65 \\
\hline 26 & Richat & 4 & 4 & 4 & 4.5 & 4.5 & 4 & 4.2 & 4.25 & $\begin{array}{l}(60 \% * 4.2)+ \\
(40 \% * 4.25)\end{array}$ & 4.17 \\
\hline 27 & Abdul & 4 & 4 & 5 & 5 & 5 & 5 & 4.75 & 4.5 & $\begin{array}{l}(60 \% * 4.75)+ \\
(40 \% * 4.5)\end{array}$ & 4.65 \\
\hline 28 & Yakub & 4 & 5 & 4 & 4.5 & 5 & 5 & 4.5 & 4.75 & $\begin{array}{l}(60 \% * 4.5)+ \\
(40 \% * 4,75)\end{array}$ & 4.65 \\
\hline 29 & Roni & 4 & 5 & 4 & 5 & 5 & 4 & 4.25 & 5 & $\begin{array}{l}(60 \% * 4.25)+ \\
(40 \% * 5)\end{array}$ & 4.55 \\
\hline
\end{tabular}




\begin{tabular}{|l|l|c|c|c|c|c|c|c|c|c|c|}
30 & Arol & 5 & 5 & 4 & 4.5 & 5 & 5 & 4.75 & 4.75 & $\begin{array}{c}(60 \% * 4.75)+ \\
(40 \% * 4,75)\end{array}$ & 4.75 \\
\hline 31 & Alysia & 5 & 5 & 4 & 4.5 & 5 & 5 & 4.75 & 4.75 & $\begin{array}{c}(60 \% * 4.75)+ \\
(40 \% * 4,7)\end{array}$ & 4.75 \\
\hline 32 & Budi & 5 & 4 & 4 & 5 & 4.5 & 4 & 4.37 & 4.5 & $\begin{array}{c}(60 \% * 4.37)+ \\
(40 \% * 4.5)\end{array}$ & 4.42 \\
\hline 33 & Tomi & 5 & 4 & 4 & 5 & 5 & 4 & 4.5 & 4.5 & $\begin{array}{c}(60 \% * 4.5)+ \\
(40 \% * 4.5)\end{array}$ & 4.5 \\
\hline
\end{tabular}

Information :

A. Core factor $(\mathrm{CF})$

B. Secondary factor (SF)

C. Core factor value

D. Secondary Factor Value

E. Total value
$=$ quality of work, accuracy, diligence, discipline $(\mathrm{A}+\mathrm{C}+\mathrm{E}+\mathrm{F}) / 4=\mathrm{CF}$

$=$ Work quantity, Efficiency $(\mathrm{B}+\mathrm{D}) / 2=\mathrm{SF}$

$=60 \% *$ core factor

$=40 \% *$ Secondary factor

$=$ result of core factor + secondary factor

\begin{tabular}{|c|c|c|c|c|c|c|c|c|c|c|c|c|c|c|c|c|c|c|c|c|c|c|}
\hline \multirow{3}{*}{$\begin{array}{l}\text { No } \\
1\end{array}$} & \multicolumn{8}{|c|}{$\begin{array}{c}\text { Self-Assessment Potential Employee } \\
\text { Criteria (A) }\end{array}$} & \multicolumn{7}{|c|}{ Number of job criteria gaps (B) } & \multicolumn{6}{|c|}{ Number of gaps (A - B) } & \multirow[b]{3}{*}{-1} \\
\hline & potential & 1 & 2 & 3 & 4 & 5 & 6 & 7 & \multicolumn{7}{|c|}{ The standard value of self potential } & 1 & 2 & 3 & 4 & 5 & 6 & \\
\hline & Rudy & 5 & 4 & 5 & 4 & 4 & 4 & 4 & 4 & 5 & 5 & 5 & 5 & 4 & 5 & 0 & -1 & 0 & -1 & -1 & 0 & \\
\hline 2 & Fenarly & 4 & 4 & 4 & 5 & 4 & 4 & 4 & 4 & 5 & 5 & 5 & 5 & 4 & 5 & 0 & -1 & -1 & 0 & -1 & 0 & -1 \\
\hline 3 & Fidellis & 4 & 4 & 4 & 4 & 5 & 4 & 4 & 4 & 5 & 5 & 5 & 5 & 4 & 5 & 0 & -1 & -1 & -1 & 0 & 0 & -1 \\
\hline 4 & Wita & 5 & 5 & 5 & 4 & 5 & 4 & 4 & 4 & 5 & 5 & 5 & 5 & 4 & 5 & 1 & 0 & 0 & -1 & 0 & 0 & -1 \\
\hline 5 & Rina & 4 & 5 & 4 & 4 & 4 & 4 & 4 & 4 & 5 & 5 & 5 & 5 & 4 & 5 & 0 & 0 & -1 & -1 & -1 & 0 & -1 \\
\hline 6 & Yuni & 4 & 4 & 4 & 4 & 5 & 4 & 4 & 4 & 5 & 5 & 5 & 5 & 4 & 5 & 0 & -1 & -1 & -1 & 0 & 0 & -1 \\
\hline 7 & Jose fung & 5 & 5 & 4 & 4 & 4 & 4 & 4 & 4 & 5 & 5 & 5 & 5 & 4 & 5 & 1 & 0 & -1 & -1 & -1 & 0 & 1 \\
\hline 8 & Hartana & 4 & 4 & 4 & 5 & 4 & 4 & 4 & 4 & 5 & 5 & 5 & 5 & 4 & 5 & 0 & -1 & -1 & 0 & -1 & 0 & -1 \\
\hline 9 & Hary & 5 & 5 & 5 & 5 & 4 & 4 & 4 & 4 & 5 & 5 & 5 & 5 & 4 & 5 & 1 & 0 & 0 & 0 & -1 & 0 & -1 \\
\hline 10 & Andi & 5 & 4 & 4 & 4 & 4 & 4 & 4 & 4 & 5 & 5 & 5 & 5 & 4 & 5 & 1 & -1 & -1 & -1 & -1 & 0 & -1 \\
\hline 11 & Akbar & 5 & 4 & 5 & 4 & 4 & 4 & 4 & 4 & 5 & 5 & 5 & 5 & 4 & 5 & 1 & -1 & 0 & -1 & -1 & 0 & -1 \\
\hline 12 & Subhana & 4 & 4 & 4 & 5 & 4 & 4 & 4 & 4 & 5 & 5 & 5 & 5 & 4 & 5 & 0 & -1 & -1 & 0 & -1 & 0 & -1 \\
\hline 13 & Iskandar & 4 & 4 & 4 & 4 & 5 & 4 & 4 & 4 & 5 & 5 & 5 & 5 & 4 & 5 & 0 & -1 & -1 & -1 & 0 & 0 & -1 \\
\hline 14 & Frendy & 5 & 5 & 5 & 4 & 5 & 4 & 4 & 4 & 5 & 5 & 5 & 5 & 4 & 5 & 1 & 0 & 0 & -1 & 0 & 0 & -1 \\
\hline 15 & Chatrine & 4 & 5 & 4 & 4 & 4 & 4 & 4 & 4 & 5 & 5 & 5 & 5 & 4 & 5 & 0 & 0 & -1 & -1 & -1 & 0 & -1 \\
\hline 16 & Abidin & 4 & 4 & 4 & 4 & 5 & 4 & 4 & 4 & 5 & 5 & 5 & 5 & 4 & 5 & 0 & -1 & -1 & -1 & 0 & 0 & -1 \\
\hline 17 & Sutandi & 5 & 5 & 4 & 4 & 4 & 4 & 4 & 4 & 5 & 5 & 5 & 5 & 4 & 5 & 1 & 0 & -1 & -1 & -1 & 0 & -1 \\
\hline 18 & Benny & 4 & 4 & 4 & 5 & 4 & 4 & 4 & 4 & 5 & 5 & 5 & 5 & 4 & 5 & 0 & -1 & -1 & 0 & -1 & 0 & -1 \\
\hline 19 & Susanto & 5 & 5 & 5 & 5 & 4 & 4 & 4 & 4 & 5 & 5 & 5 & 5 & 4 & 5 & 1 & 0 & 0 & 0 & -1 & 0 & -1 \\
\hline 20 & Septian & 5 & 4 & 4 & 4 & 4 & 4 & 4 & 4 & 5 & 5 & 5 & 5 & 4 & 5 & 1 & -1 & -1 & 0 & -1 & 0 & -1 \\
\hline 21 & Anik & 5 & 4 & 5 & 4 & 4 & 4 & 4 & 4 & 5 & 5 & 5 & 5 & 4 & 5 & 1 & -1 & 0 & -1 & -1 & 0 & -1 \\
\hline
\end{tabular}




\begin{tabular}{|l|l|l|l|l|l|l|l|l|l|l|l|l|l|l|l|l|l|l|l|l|l|l|}
22 & Saipul & 4 & 4 & 4 & 5 & 4 & 4 & 4 & 4 & 5 & 5 & 5 & 5 & 4 & 5 & 0 & -1 & -1 & 0 & -1 & 0 & -1 \\
\hline 23 & Anwar & 4 & 4 & 4 & 4 & 5 & 4 & 4 & 4 & 5 & 5 & 5 & 5 & 4 & 5 & 0 & -1 & -1 & -1 & 0 & 0 & -1 \\
\hline 24 & Gocang & 5 & 5 & 5 & 4 & 5 & 4 & 4 & 4 & 5 & 5 & 5 & 5 & 4 & 5 & 1 & 0 & 0 & -1 & 0 & 0 & -1 \\
\hline 25 & Dhea & 4 & 5 & 4 & 4 & 4 & 4 & 4 & 4 & 5 & 5 & 5 & 5 & 4 & 5 & 0 & 0 & -1 & -1 & -1 & 0 & -1 \\
\hline 26 & Richat & 4 & 4 & 4 & 4 & 5 & 4 & 4 & 4 & 5 & 5 & 5 & 5 & 4 & 5 & 0 & -1 & -1 & -1 & 0 & 0 & -1 \\
\hline 27 & Abdul & 5 & 5 & 4 & 4 & 4 & 4 & 4 & 4 & 5 & 5 & 5 & 5 & 4 & 5 & 1 & 0 & -1 & -1 & -1 & 0 & -1 \\
\hline 28 & Yakub & 4 & 4 & 4 & 5 & 4 & 4 & 4 & 4 & 5 & 5 & 5 & 5 & 4 & 5 & 0 & -1 & -1 & 0 & -1 & 0 & -1 \\
\hline 29 & Roni & 5 & 5 & 5 & 5 & 4 & 4 & 4 & 4 & 5 & 5 & 5 & 5 & 4 & 5 & 1 & 0 & 0 & 0 & -1 & 0 & -1 \\
\hline 30 & Arol & 5 & 4 & 4 & 4 & 4 & 4 & 4 & 4 & 5 & 5 & 5 & 5 & 4 & 5 & 1 & -1 & -1 & -1 & -1 & 0 & -1 \\
\hline 31 & Alysia & 5 & 4 & 5 & 4 & 4 & 4 & 4 & 4 & 5 & 5 & 5 & 5 & 4 & 5 & 1 & -1 & 0 & -1 & -1 & 0 & -1 \\
\hline 32 & Budi & 4 & 4 & 4 & 5 & 4 & 4 & 4 & 4 & 5 & 5 & 5 & 5 & 4 & 5 & 0 & -1 & -1 & 0 & -1 & 0 & -1 \\
\hline 33 & Tomi & 4 & 4 & 4 & 4 & 5 & 4 & 4 & 4 & 5 & 5 & 5 & 5 & 4 & 5 & 0 & -1 & -1 & -1 & 0 & 0 & -1 \\
\hline
\end{tabular}

Table 10 Equation Potential Gap Table Self

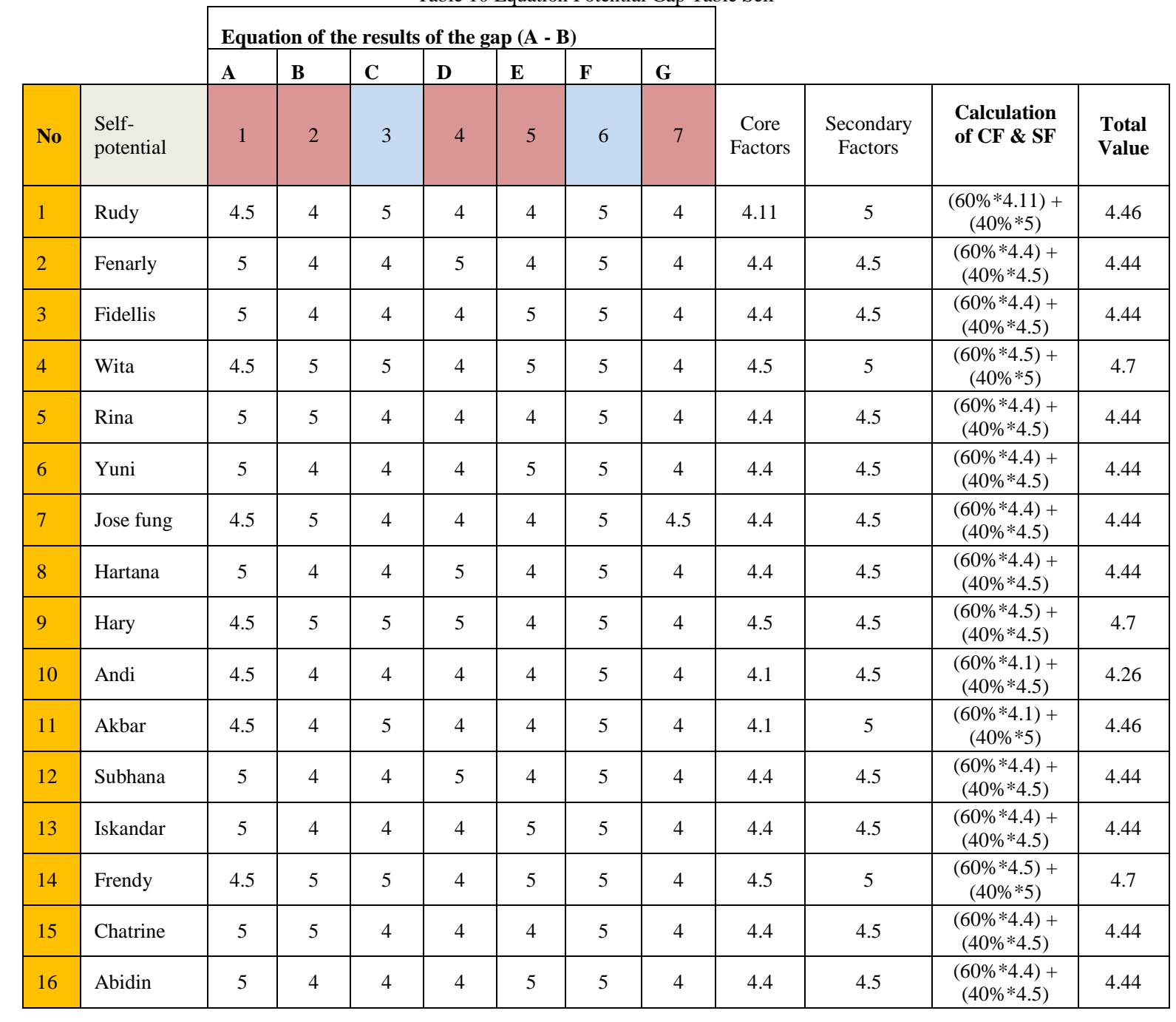




\begin{tabular}{|c|c|c|c|c|c|c|c|c|c|c|c|c|}
\hline 17 & Sutandi & 4.5 & 5 & 4 & 4 & 4 & 5 & 4 & 4.3 & 4.5 & $\begin{array}{c}(60 \% * 4.3)+ \\
(40 \% * 4.5)\end{array}$ & 4.38 \\
\hline 18 & Benny & 5 & 4 & 4 & 5 & 4 & 5 & 4 & 4.4 & 4.5 & $\begin{array}{c}(60 \% * 4.4)+ \\
(40 \% * 4.5)\end{array}$ & 4.44 \\
\hline 19 & Susanto & 4.5 & 5 & 5 & 5 & 4 & 5 & 4 & 4.5 & 5 & $\begin{array}{c}(60 \% * 4.5)+ \\
(40 \% * 5)\end{array}$ & 4.7 \\
\hline 20 & Septian & 4.5 & 4 & 4 & 5 & 4 & 5 & 4 & 4.3 & 4.5 & $\begin{array}{c}(60 \% * 4.3)+ \\
(40 \% * 4.5)\end{array}$ & 4.38 \\
\hline 21 & Anik & 4.5 & 4 & 5 & 4 & 4 & 5 & 4 & 4.1 & 5 & $\begin{array}{c}(60 \% * 4.1)+ \\
(40 \% * 5)\end{array}$ & 4.46 \\
\hline 22 & Saipul & 5 & 4 & 4 & 5 & 4 & 5 & 4 & 4.4 & 4.5 & $\begin{array}{c}(60 \% * 4.4)+ \\
(40 \% * 4.5)\end{array}$ & 4.44 \\
\hline 23 & Anwar & 5 & 4 & 4 & 4 & 5 & 5 & 4 & 4.4 & 4.5 & $\begin{array}{c}(60 \% * 4.4)+ \\
(40 \% * 4.5)\end{array}$ & 4.44 \\
\hline 24 & Gocang & 4.5 & 5 & 5 & 4 & 5 & 5 & 4 & 4.5 & 5 & $\begin{array}{c}(60 \% * 4.5)+ \\
(40 \% * 5)\end{array}$ & 4.7 \\
\hline 25 & Dhea & 5 & 5 & 4 & 4 & 4 & 5 & 4 & 4.4 & 4.5 & $\begin{array}{c}(60 \% * 4.4)+ \\
(40 \% * 4.5)\end{array}$ & 4.44 \\
\hline 26 & Richat & 5 & 4 & 4 & 4 & 5 & 5 & 4 & 4.4 & 4.5 & $\begin{array}{c}(60 \% * 4.4)+ \\
(40 \% * 4.5)\end{array}$ & 4.44 \\
\hline 27 & Abdul & 4 & 5 & 5 & 4 & 4 & 5 & 4 & 4.2 & 4.5 & $\begin{array}{c}(60 \% * 4.2)+ \\
(40 \% * 4.5)\end{array}$ & 4.52 \\
\hline 28 & Yakub & 5 & 4 & 4 & 5 & 4 & 5 & 4 & 4.4 & 4.5 & $\begin{array}{c}(60 \% * 4.4)+ \\
(40 \% * 4.5)\end{array}$ & 4.44 \\
\hline 29 & Roni & 4.5 & 5 & 4 & 4 & 4 & 5 & 4 & 4.3 & 4.5 & $\begin{array}{c}(60 \% * 4.3)+ \\
(40 \% * 4.5) \\
\end{array}$ & 4.38 \\
\hline 30 & Arol & 4.5 & 4 & 5 & 4 & 4 & 5 & 4 & 4.1 & 5 & $\begin{array}{c}(60 \% * 4.1)+ \\
(40 \% * 5)\end{array}$ & 4.46 \\
\hline 31 & Alysia & 4.5 & 4 & 4 & 5 & 4 & 5 & 4 & 4.3 & 4.5 & $\begin{array}{c}(60 \% * 4.3)+ \\
(40 \% * 4.5)\end{array}$ & 4.38 \\
\hline 32 & Budi & 5 & 4 & 4 & 5 & 4 & 5 & 4 & 4.4 & 4.5 & $\begin{array}{c}(60 \% * 4.4)+ \\
(40 \% * 4.5)\end{array}$ & 4.44 \\
\hline 33 & Tomi & 5 & 4 & 4 & 4 & 5 & 5 & 4 & 4.4 & 4.5 & $\begin{array}{c}(60 \% * 4.4)+ \\
(40 \% * 4.5)\end{array}$ & 4.44 \\
\hline
\end{tabular}

Information:
A. Core factor $(\mathrm{CF})$
B. Secondary factor (SF)
C. Core factor value
D. Secondary factor value
E. Total value
$=$ creativity / initiative, collaboration, responsibility, leadership, honesty $(\mathrm{A}+\mathrm{B}+$ $\mathrm{D}+\mathrm{E}+\mathrm{G}) / 2=\mathrm{CF}$
$=$ Ability to work alone, Obedience to carry out superior orders $(\mathrm{C}+\mathrm{F}) / 2=\mathrm{SF}$
$=60 \% *$ core factor
$=40 \% *$ secondary factor
$=$ result of core factor + secondary factor

Tabel 11. Calculation of Total Employment Value and Employee Self Potential

\begin{tabular}{|l|l|l|l|l|l|}
\hline No & Employee & $\begin{array}{l}\text { Job } \\
\text { Criteria }\end{array}$ & $\begin{array}{l}\text { Self- } \\
\text { Potential } \\
\text { Criteria }\end{array}$ & $\begin{array}{l}\text { Total } \\
\text { Value }\end{array}$ & Remarks \\
\hline 1 & Rudy & 4.6 & 4.46 & 4.53 & Salary raise \\
\hline 2 & Fenarly & 4.42 & 4.44 & 4.43 & Not worth raising salary and position \\
\hline 3 & Fidellis & 4.5 & 4.44 & 4.47 & Not worth raising salary and position \\
\hline 4 & Wita & 4.35 & 4.17 & 4.52 & Salary raise \\
\hline 5 & Rina & 4.65 & 4.44 & 4.54 & Salary raise \\
\hline 6 & Yuni & 4.17 & 4.44 & 4.3 & Not worth raising salary and position \\
\hline 7 & Jose fung & 4.65 & 4.44 & 4.54 & Salary raise \\
\hline 8 & Hartana & 4.6 & 4.44 & 4.52 & Salary raise \\
\hline
\end{tabular}




\begin{tabular}{|c|c|c|c|c|c|}
\hline 9 & Hary & 4.55 & 4.7 & 4.62 & Increase salary and position \\
\hline 10 & Andi & 4.75 & 4.26 & 4.5 & Salary raise \\
\hline 11 & Akbar & 4.75 & 4.46 & 4.6 & Increase salary and position \\
\hline 12 & Subhana & 4.52 & 4.44 & 4.48 & Not worth raising salary and position \\
\hline 13 & Iskandar & 4.5 & 4.44 & 4.47 & Not worth raising salary and position \\
\hline 14 & Frendy & 4.35 & 4.7 & 4.52 & Salary raise \\
\hline 15 & Chatrine & 4.65 & 4.44 & 4.54 & Salary raise \\
\hline 16 & Abidin & 4.27 & 4.44 & 4.35 & Not worth raising salary and position \\
\hline 17 & Sutandi & 4.65 & 4.38 & 4.52 & Salary raise \\
\hline 18 & Benny & 4.6 & 4.44 & 4.52 & Salary raise \\
\hline 19 & Susanto & 4.55 & 4.7 & 4.62 & Increase salary and position \\
\hline 20 & Septian & 4.75 & 4.38 & 4.57 & Salary raise \\
\hline 21 & Anik & 4.6 & 4.46 & 4.53 & Salary raise \\
\hline 22 & Saipul & 4.38 & 4.44 & 4.41 & Not worth raising salary and position \\
\hline 23 & Anwar & 4.5 & 4.44 & 4.47 & Not worth raising salary and position \\
\hline 24 & Gocang & 4.35 & 4.7 & 4.52 & Salary raise \\
\hline 25 & Dhea & 4.65 & 4.44 & 4.54 & Salary raise \\
\hline 26 & Richat & 4.17 & 4.44 & 4.3 & Not worth raising salary and position \\
\hline 27 & Abdul & 4.65 & 4.52 & 4.58 & Salary raise \\
\hline 28 & Yakub & 4.6 & 4.42 & 4.51 & Salary raise \\
\hline 29 & Roni & 4.55 & 4.38 & 4.46 & Not worth raising salary and position \\
\hline 30 & Arol & 4.75 & 4.46 & 4.6 & Increase salary and position \\
\hline 31 & Alysia & 4.75 & 4.38 & 4.56 & Salary raise \\
\hline 32 & Budi & 4.42 & 4.44 & 4.43 & Not worth raising salary and position \\
\hline 33 & Tomi & 4.5 & 4.44 & 4.47 & Not worth raising salary and position \\
\hline
\end{tabular}

Note: The results of the merging of the core factor and secondary factor assessment of employee performance using the profile matching method consisting of job criteria and self-potential criteria that is value 4,62 = Hary, susanto, 4,60 = Akbar, Arol, 4,58 = Abdul, 4,57 = Septian, 4,56 = Alysia, 4,54 = Dhea, Rina, Jo se fung, Chatrine, 4,53= Anik, Rudy, 4,52 = Gocang, Sutandi, Benny, frendy, Hartana, Wita, 4,50 = Andi, 4,51 = Yakub, 4,48 = Subhana, 4,47 = Tomi, iskandar, fidellis, Anwar, 4,46 = Roni, 4,43 = Budi, fenarly, 4,41 = Saipul, 4,35 = Abidin, 4,30 = Richat, Yuni, And that can be recommended for salary and position increases are at 4.62 and 4.60. Which can be recommended for salary increases are at values $4.58,4.57,4.56,4.54,4.53,4.52,4.51,4.50$, and those that are not eligible for a raise and are at 4.48, 4.47, 4.46, 4.43, 4.41, 4.35, 4.30, 4.30 which can be recommended for salary increases and positions must reach a minimum value of 4.60. and those recommended for salary increases of at least 4.50 and those who are not eligible for a raise in salary and position have a minimum value of 4.40. Based on the calculation of 33 eligible employees, it is recommended to raise salaries and positions of 4 employees and those who are eligible are recommended to raise 17 employees. That is not feasible to be recommended for salary increases and positions of 12 employees. 
Table 12. Comparison of Employee Performance Appraisal with the Simple Additive Weight (SAW) Method

\begin{tabular}{|c|c|c|c|c|}
\hline \multicolumn{3}{|c|}{ The SAW method } & \multicolumn{2}{|r|}{ Profile Matching Method } \\
\hline Employee name & Total Value & Information & Total Value & Information \\
\hline Rudy & 0,97 & Salary raise & 4.53 & Salary raise \\
\hline Fenarly & 0,908 & Not worth raising salary and position & 4.43 & Not worth raising salary and position \\
\hline Fidellis & 0,9 & Not worth raising salary and position & 4.47 & Not worth raising salary and position \\
\hline Wita & 0,9405 & Salary raise & 4.52 & Salary raise \\
\hline Rina & 0.928 & Not worth raising salary and position & 4.54 & Salary raise \\
\hline Yuni & 0,937 & Not worth raising salary and position & 4.3 & Not worth raising salary and position \\
\hline Jose fung & 0,946 & Salary raise & 4.54 & Salary raise \\
\hline Hartana & 0,922 & Not worth raising salary and position & 4.52 & Salary raise \\
\hline Hary & 0,967 & Salary raise & 4.62 & deserve a raise in salary and position \\
\hline Andi & 0,9505 & Salary raise & 4.5 & Salary raise \\
\hline Akbar & 0,9475 & Salary raise & 4.6 & deserve a raise in salary and position \\
\hline Subhana & 0,908 & Not worth raising salary and position & 4.48 & Not worth raising salary and position \\
\hline Iskandar & 0,9 & Not worth raising salary and position & 4.47 & Not worth raising salary and position \\
\hline Frendy & 0,9405 & Salary raise & 4.52 & Salary raise \\
\hline Chatrine & 0,944 & Salary raise & 4.54 & Salary raise \\
\hline Abidin & 0,921 & Not worth raising salary and position & 4.39 & Not worth raising salary and position \\
\hline Sutandi & 0,946 & Salary raise & 4.51 & Salary raise \\
\hline Benny & 0,9415 & Salary raise & 4.54 & Salary raise \\
\hline Susanto & 0,967 & Salary raise & 4.62 & deserve a raise in salary and position \\
\hline Septian & 0,9505 & Salary raise & 4.56 & Salary raise \\
\hline Anik & 0,97 & Salary raise & 4.53 & Salary raise \\
\hline Saipul & 0,908 & Not worth raising salary and position & 4.41 & Not worth raising salary and position \\
\hline Anwar & 0,9 & Not worth raising salary and position & 4.47 & Not worth raising salary and position \\
\hline Gocang & 0,9405 & Salary raise & 4.52 & Salary raise \\
\hline Dhea & 0,928 & Not worth raising salary and position & 4.54 & Salary raise \\
\hline Richat & 0,937 & Not worth raising salary and position & 4.3 & Not worth raising salary and position \\
\hline Abdul & 0,946 & Salary raise & 4.58 & Salary raise \\
\hline Yakub & 0,9415 & Salary raise & 4.54 & Salary raise \\
\hline Roni & 0,967 & Salary raise & 4.46 & Not worth raising salary and position \\
\hline Arol & 0,9475 & Salary raise & 4.6 & deserve a raise in salary and position \\
\hline Sherly & 0,97 & Salary raise & 4.56 & Salary raise \\
\hline Budi & 0,908 & Not worth raising salary and position & 4.43 & Not worth raising salary and position \\
\hline Tomi & 0,9 & Not worth raising salary and position & 4.47 & Not worth raising salary and position \\
\hline
\end{tabular}

Table 13. Comparative Results Of The Saw Method And The Game Profile

\begin{tabular}{|l|c|c|}
\hline \multicolumn{1}{|c|}{ Information } & The SAW method & Profile Matching Method \\
\hline Salary raise & 19 & 17 \\
\hline Not worth raising salary and position & 14 & 12 \\
\hline deserve a raise in salary and position & 0 & 4 \\
\hline
\end{tabular}




\begin{tabular}{|l|l|l|} 
total respondents & 33 & 33 \\
\hline
\end{tabular}

Note: The results of employee performance values use the profile matching method with information worth raising salaries by 17 employees, then with information not worth raising salaries and positions by 12 employees, and information worth raising salaries and positions by 4 employees. And comparing with the Simple Additive Weight (SAW) method, there are 19 employees who are eligible to raise salaries and 14 employees who are not eligible to raise salaries and positions.

\section{CONCLUSIONS}

The results of calculations using the Core Factor (CF) profile matching method look for more important data, the secondary factor (SF) searches for less important data. The results of the merging of the core factor and secondary factor assessment of employee performance using the profile matching method which consists of job criteria and selfpotential criteria, namely the value 4,62 $=$ Hary, susanto, 4,60 $=$ Akbar, Arol, 4,58 $=$ Abdul, 4,57 $=$ Septian, 4,56 $=$ Alysia, 4,54 = Dhea, Rina, Jo se fung, Chatrine, 4,53 = Anik, Rudy, 4,52 = Gocang, Sutandi, Benny, frendy, Hartana, Wita, 4,50 = Andi, 4,51 = Yakub, 4,48 = Subhana, 4,47 = Tomi, iskandar, fidellis, Anwar, 4,46 = Roni, 4,43 = Budi, fenarly, 4,41 = Saipul, 4,35 = Abidin, 4,30 = Richat, Yuni. And that can be recommended for salary increases and positions of 4 employees. Which can be recommended for salary increases there are 17 employees and those who are not eligible for salary increases and positions are valued at 12 employees.

Comparison of the Profile Matching Method with the Simple Additive Weight (SAW) Method, the results of the employee's performance value using the profile matching method with information worth raising salaries of 17 employees, then with information not worth raising salaries and positions of 12 employees, and information worth raising salaries and positions as many as 4 employees, and compare with the Simple Additive Weight (SAW) method, there are 19 employees who are eligible to raise salaries and 14 employees who are not eligible to raise salaries and positions.

\section{REFERENCES}

[1] A. Suhartanto, Kusrini and Henderi, "Decision support system untuk penilaian kinerja guru dengan metode profile matching," Bianglala Informatika, vol. 4, no. 2, 2016.

[2] M. Moedjiono, A. H. Wijaya and A. Kusdaryono, "Sistem Informasi Penilaian Dosen Berbasis Web Menggunakan Metode Profile Matching," in Seminar Nasional Vokasi dan Teknologi (SEMNASVOKTEK), Denpasar-Bali, 2016.

[3] K. Konsep dan aplikasi sistem pendukung keputusan, Yogyakarta, 2007.

[4] H. G. Munthe, "Sistem Pendukung Keputusan Penentuan Prioritas Usulan Sertifikasi Guru Dengan Metode Simple Additive Weighting," Jurnal informatika, vol. IV, no. 2, 2013.

[5] V. Business Inteligence : Datamining and Optimazation for Decision Making, Chichester: Wiley., 2009. 